\title{
Postmodern Lifestyle Construction
}

\author{
(Norman Fairclough Discourse Analysis on Journal Website Content \\ www.maternaldisaster.com)
}

\author{
Mohammad Iqbal Maulana*, Aning Sofyan, Kiki Zakiah \\ Bandung Islamic University \\ Bandung, Indonesia \\ soaliqbal@gmail.com*, aningsofyan@gmail.com, kikizakiah@gmail.com
}

\begin{abstract}
The problem is increasingly postmodern developing, where the flow of media consumption develops simultaneously from production to reproduction. The dynamics of media consumption and popular culture become such a subculture identity in the realm of social order. This study aims to describe the postmodern lifestyle discourse in representing brand identity. The research method used is a qualitative method with a constructivist paradigm. The analytical technique used in this study is Norman Fairclough Critical Discourse Analysis using three levels of analysis, namely, discourse practice and sociocultural practice. The results show that the postmodern lifestyle discourse by the horror discourse can be seen as an expressive form of the brand. By taking the fragmentation reference of ideas from discourse popular culture of postmodern horror films, such as the concept of hyperreality and hybridity from popular culture to being making innovation and creativity in the development of a streetwear product business. The Text discourse is a form of film media consumption that is then rediscouraged through their media platforms. So that brand activity in consuming the film culture is a way of forming differentiation and alternatives.
\end{abstract}

Keywords—postmodern, discourse, media

\section{INTRODUCTION}

The birth of the term postmodernism in the sociocultural universe is not something that just sticks out. This phenomenon was born as a result of modernism itself. There has been criticism from postmodernists regarding the concept of knowledge and thinking of modernists during this time. Simply put, there are some assessments of the concept of progress or things that are currently in the culture of modernism whips are seen as pragmatic, and postmodernists criticize the concept of progress or establishment of modernism which is considered too linear and static. If it is analogized to the mention of colors, modernism always plays only on black and white colors, while postmodernism calls for one more color between the two colors, there is a gray tint that modernism does not see.

Adian said that many people misinterpret postmodernism as a further development of modernism. The word "Pos" in postmodernism is often understood as "post", "after" in the sense of a time sequence, progress beyond modernism. This understanding is misleading because postmodernism is very "anti" to ideas, such as progress, emancipation, historical linearity, and so on [1]. This means postmodernism and modernism become a struggle in grouping people in taking action, attitude, and identity. And no leaning on the linkage of civilizations of an era. Even in this kind of situation, the dynamics of postmodern problems today are not limited to a particular tradition or a school of thought,

According to David Chaney [2] describes a lifestyle as a style, procedure, or way of using goods, places, and times, typical of certain groups of people, which are highly dependent on cultural forms. Chaney [2] continues with a lifestyle that can help define attitudes of person, values, and social position. Lifestyles also become important today, since humans often practice habits and even classify groups of people with one another as a form of identity expression.

Postmodern lifestyle discourse positions audiences in differentiation and alternative styles that influence their concept of thinking. Differentiation refers to differences or does not want to be confused with a modernist cultural style that tends to be completely structural or uniform. The striking difference in how to characterize the differentiation adopted by postmodernists and modernists is that the formation of differentiation from modernists is more distinctive towards uniformity, whereas postmodernists are differences that are not to be uninformed. As for the alternative itself, for postmodernists how to position themselves on a path that is not mainstream in the sense of leaving the big narrative standard or the structural nature of the modernists.

Lubis [3] says that postmodernists themselves generally do not like uniformity and do not like definitions or restrictions, but prefer and accept differences. Therefore, the concept of difference (difference) is one of the key concepts (important concepts) in postmodern thinking in addition to other concepts. This emphasis on difference, diversity, anti-essentiality is a way of thinking that is different from the way of thinking that prioritizes universality, unity, and essentiality which was very dominant in the previous paradigm (modern paradigm).

The massive development of postmodernism discourse in the social world cannot be separated from the current 
development of media consumption and popular culture is accepted by a growing audience simultaneously, from consumption to production. In the realm of media and culture, postmodernism closely intersects popular culture practices. This is in line with what Burton [4] says that Postmodernism is about the study of forms of popular culture. Where the process of assimilation and acculturation of postmodern knowledge can be seen from how the media offer representations of messages about postmodern constructions in their texts.

The cultural practice of popular culture by young people is the most highly involved factor so that the current of postmodernism is attached to idealism and the existence of contemporary audiences today. Besides, postmodern discourse seems to influence contemporary media culture, especially how humans build power relations to build their identities, as in popular culture which has been indexed by the expression of young people.

It is on this basis that the researcher wants to examine the practice of postmodern styles that are absorbed by a brand by the tendency to consume popular culture which is produced and reproduced on a new media website platform from the brand institution. Researchers chose the Maternal Disaster brand by looking at the Journal content from their media platform, which contains various film reviews on how to see between the position of the text with the authors and the Maternal Disaster brand institution. By using Norman Fairclough critical discourse analysis model, by examining three levels, namely text, discourse practice, and sociocultural practice. Therefore the title of this research is Postmodern Lifestyle Construction (Norman Fairclough Discourse Analysis on Journal Content Website www.maternaldisaster.com).

\section{LITERATURE REVIEW}

\section{A. Identity and Social Construction in Media}

In essence, media content is the result of reality construction with language as its basic tool. Meanwhile, language is not only a means of representing reality, but it can also determine what relief language will create this reality. As a result, the mass media has a very big opportunity to influence the meaning and image that results from the reality it constructs [5].

The term social construction of reality has become famous since it was introduced by Peter L. Berger and Thomas Luckman through their book entitled The Social Construction of Reality: A Treatise in the Sociological of Knowledge [6]. Kriyantono explains that the main actor in this theory says that reality is socially constructed when a person or group interacts together in a social system. An individual and society are formed in a social system. Continuous interaction. Society is not only a product of the interaction between individuals in it but also influences the behavior of individuals in it [5].

The substance of the theory and social construction approach to reality from Berger and Luckmann [6] is a simultaneous process that occurs naturally through language in everyday life in a primary and semi-secondary community. The social basis of this theory and approach is the modern transition in America around the 1960s, where the mass media has not yet become an interesting phenomenon to talk about. Thus, Berger and Lucman [6] do not include mass media as a variable or phenomenon that influences the social construction of reality. The constructed reality also forms a mass opinion, the masses tend to be a priori, and mass opinion tends to be cynical [1].

So, in this study, the researcher wanted to see the identity constructed in the media in determining the position of an individual in a group. Sack (in De Fina, Schriffrin, and Bamberg [7]) states that identity construction is related to two terms, namely the inclusive and exclusive categories of individuals in the majority society, which can be seen from the daily activities of each member of society. De Fina [7] explain that identity is seen not as a product, but as a process that occurs in social interactions, which are embedded in daily discourse practices. This means that identity is not born just like that but is formed by elements of society so that identity is dynamic,

From a postmodern point of view, as the pace, expansion, and complexity of modern society increases, identity becomes more and more unstable, more and more fragile. In a situation like this, postmodernity discourse questions the idea of identity, stating that identity is just a myth and an illusion [8].

Baudrillard describes the emergence of a postmodern society organized through simulation, in which models, code, communication, information, and media are the causes of radical fractures with modern society. In his intoxicating postmodern life, subjectivity is fragmented and lost, while a series of new experiences emerge, making social theories outdated and irrelevant [8].

\section{B. Discourse Analysis by Norman Fairclough}

Discourse analysis or discourse analysis is a method or method of studying the discourse contained in communication messages both textually and contextually. Discourse analysis is concerned with the content of communication messages, some of which are text [9].

Discourse research does not provide concrete or visible answers to problems in scientific research but provides tools to be able to find out the assumptions of epistemology (philosophical basis, nature) and ontology (the philosophical basis of existence, life) that lie behind scientific research, the life of the problem, and the research methods used/used. Discourse researchers assume that each text has been conditioned/constructed and embedded in the discourse that has been formed, or discourse analysis is used to deconstruct what has been made or given discourse [10].

Fairclough (in Piliang and Jaelani [11]) emphasizes his attention to language as an exercise of power. Fairclough tries to analyze the practice of power in language by connecting the social context of a society with text analysis based on 
linguistics. Discourse in Fairclough understanding has three effects: first, the discourse has a role in constructing social identity and subject positions. Second, discourse helps construct social identities among people. Third, discourse contributes to constructing knowledge and belief systems. The three effects of this discourse are a function of language and the dimensions of meaning associated with identity, relational, and ideational functions of language.

Fairclough divides discourse analysis into three dimensions/structures: text, discourse practice, and sociocultural practice. In the Fairclough model, the text here is analyzed linguistically, by looking at vocabulary, semantics, and sentence structure. It also includes coherence and cohesiveness, how words or sentences are combined to form meaning [12].

Then, discourse practice is a dimension related to the production and consumption of text. A text is produced through different text production processes, such as how to work patterns, work charts, routines in producing news. News texts are produced in a specific way with routine and structured work patterns where journalists report in the field, or from news sources to be written by editors, and so on [12].

And, sociocultural practice is a dimension related to contexts outside the text. The context here includes many things such as the context of the situation, more broadly, the context of the institutional practices of the media itself in relation to a particular society or culture and politics. For example, media politics, media economics, or certain media culture influence the news it produces [12].

\section{Media and Ideological Exposure}

That the role of media and ideology is a package that is always sustainable because things around us are influenced by ideology. Society produces ideology through the media, then, from the media ideology is produced, from that ideology, it is produced back into society. This is as stated by Santana in his book Contemporary Journalism [13], the news contains ideology. Media, and its issues, are reproductions of society. Every society contains an ideology. Every nation has an ideology. And every ideology does not stand alone, it is always related to many things in life of people. Community life correlates with the expectations, norms, actions, images, and the like, of the various groups that live in the community. Various events, in public life, therefore, implies "ideological content". And, when reported, the news represents an ideology, as well as reproduces a certain ideology.

Seeing this phenomenon, it means that ideology becomes an important discursive in labeling society. But concretely what is meant by ideology? Etymologically, ideology comes from Greek, consisting of the idea and logia of the words. The idea comes from the word idein which means to see. The idea in New Collegiate Webster Dictionary means "something existing in the mind as the result of the formulation of an opinion, a plan or the like" (something that is in the mind as a result of the formulation of thought or plan). Meanwhile, logically comes from the word logos which means word. This word comes from the word legein which means to speak. Furthermore, the word logia mean science (knowledge) or theory. So, ideology according to the meaning of the pronounced pronunciation of what is seen or what utters in the mind as a result of thoughts [5].

\section{New Media}

The era of new media began to roll, the old mass media which was dominated by print, radio and television, found new competitors with the presence of information technology, especially the Internet. New media or new media are all forms of all digital communication media, derived from the word Digitus which means fingers. Digital is a depiction of the existence of numbers consisting of the numbers 0 and 1 or off and on which are called binary numbers. All computer systems use digital systems, as their database. New media give new meaning to communicate without boundaries. The new media will eliminate geographic boundaries, allowing for an increase in the volume of communication, speed of communication transfer, interactive communication and all forms of communication to mingle and integrate. New media such as the Internet have replaced the traditional one-to-many communication models through Web communications. According to Kotler and Armstrong, the Internet is a global network of extensive and growing computer networks without any central management or ownership. Today, the Internet connects individuals and companies and with information around the world. The Internet provides a connection to information, entertainment and communication anytime, anywhere [14]. The Internet connects individuals and companies and with information around the world. The Internet provides a connection to information, entertainment, and communication anytime, anywhere [14]. The Internet connects individuals and companies and with information around the world. The Internet provides a connection to information, entertainment, and communication anytime, anywhere [14].

Bolter and Grusin, as quoted in Heryanto [15], explained that new media content, such as the worldwide web (internet site), is a combination of new media content that already exists in different formats, such as in newspaper writing, photography, film, music, television, and reproduced and converted into digital media after experiencing the development of generations.

The internet is a part of cyberspace. As Alisjahbana puts it, cyberspace is more like an ecological system (the biosphere, for example) than a machine. Cyberspace, according to Alisjahbana, is a space that is always around or near telephone wires, coaxial cables, fiber-optic cables, and electromagnetic waves. The entire cyberspace is inhabited by various kinds of knowledge including false or incorrect knowledge or ideas [16]. 


\section{METHODS}

The method used in this research is the Discourse Analysis Method. Discourse analysis is a broad set of methodological principles applied to speech and text forms/speech, both naturally occurring and pre-planned. In research, discourse analysis can be used singly or in conjunction with other methodological approaches, such as ethnography or case studies. Sources of data for discourse analysis include interviews, conversations, articles, newspapers, press releases, media, television news broadcasts, company policy documents, correspondence, reports, even informal conversations, such as radio announcer talks [17].

In this research, the writer uses a qualitative research approach. Qualitative research is research that uses open interviews to examine and understand the attitudes, views, feelings, and behavior of an individual or group of people [18].

The analysis technique used in this research is discourse analysis using Norman Fairclough model framework. Through methods In this discourse analysis, analysis of three levels will be carried out including text, discourse practice, and sociocultural practice.

\section{RESULTS AND DISCUSSION}

Text dissection in this study using the scalpel of discourse analysis by Norman Fairclough model, with three-dimensional levels of analysis, namely text, discourse practice, and sociocultural practice.

\section{A. Text Analysis}

In the text analysis, the Norman Fairclough model divides the text into three dimensions, namely representation, relations, and identity. The following is a text analysis of the three film review texts from the Journal content on www.maternaldisaster.com:

\section{1) Video Drome}

a) Representation: Postmodern discourse involving horror identities, as in the following text which presents the form of postmodern representations. "However, Video drome by Cronenberg is not a pure horror/science fiction film. It is also a satirical work full of criticism and symbols to describe the commercial rise of television entertainment as a medium capable of brainwashing its viewers, a medium capable of shaping and influencing human behavior, and establishing a special intimate relationship between humans and their television screens "

The author writes the clause "not pure", this sentence refers to the intactness or mixing of one element with another, if it is linked to a cultural condition, this is related to the mixing of a culture or concept from the horror film itself, where the nature of originality or identity from horror and the dangers of horror, it is not always related to supernatural things, even more, contradictory to the projection of image to the realm of the media or science.
Here the media is worried about being a frightening instrument because it can brainwash the audience. Moreover, the postmodern style of horror has its own beyond imagination, the concept of hyperreality is closely related to social critical thinking with a satirical pattern.

b) Relation: The text of the Drome Video reviewer in its relation seeks to present an educational awareness of what horror film connoisseurs need to know about the works of the director. How the film can be an interesting recommendation based on the storyline built by the director, and the writer also tries to tell how the influence of the director who tries to appear in his film works, such as a reference to ideas of the director so that horror movie lovers also know how horror is involved. represented, has a strong foundation in conveying messages in the film.

For example, in the sentence "horror film fans are certainly familiar with this name, and of course, they are very familiar with the characteristics of Croneberg in working on horror films; body horror, psychological, technology, infection, violence, and sexuality "from the sentence, it can be seen that the writer tries to emphasize that the participant in the text, namely Croneberg, has provided limits and knowledge about the exclusivity of the characters in his horror film stories that are not just horror films that are commonly known to many people. , the concept of horror which contains various categorizations put together in one story such as body horror, psychological, technology, infection, violence, and sexuality. This is also an identifier to horror film lovers having distinctive differentiation and alternatives summarized in Croneberg film work.

Then proceed to the following sentence "Croneberg work was also influenced by the writings of Marshall McLuhan, an intellectual, philosopher, and communication lecturer who also came from Canada. In the mid-1960s McLuhan gave lectures and wrote many books on how the communication media (newspapers, photos, advertisements, films, television broadcasting, radio, etc.) shaped the control of society. I am not an expert in this field, so if you are interested, please find out more about McLuhan, or please ask your communication lecturer. text participants in his film work were influenced by the ideas of media and communication scientists such as Marshall McLuhan. Then, the writer also gives a relationship to horror film lovers as well as an exclusive affirmation of horror. Besides, the relationship effort that you want to construct for horror film connoisseurs does not only stop at the viewing stage, the culture of exchanging opinions and ideas on scientific science in horror films is an important concern in providing alternative discourse to horror film connoisseurs.

c) Identity: In the text, the writer identifies himself as a pro in responding to the Video Drome film. This is shown in the sentence the writer puts forward in expressing his opinion in the form of a statement, such as in the following sentence, "Maybe the implicit message that Cronenberg wants to convey is, turn off your television before it becomes a reality for you" by looking at the assumptions of the text written by the 
author, explains that the writer and Croneberg in the film have the same pretext regarding the horror / dangerous of the media industry over the power of the media to the audience which is imaged in a horror style. The sentence is also, apart from being a critical discourse,

This is emphasized by the following sentence, "If you think about it further, actually the theme in this film is still relevant today, where the influence (which is not only television but the internet as well) on human behavior and culture can be said to be getting stronger. Moreover, about sex and violence," the sentence makes it clearer that the writer has his observations about the horror influence of media content. The author also believes that the dominant discourse does not only apply to television media alone, internet media also has the same dominance.

\section{2) Super Dark Times}

a) Representation: For the construction of the postmodern style represented in the text is how the life position of teenagers is mediocre, which then the plot is presented differently into a tragic and horror situation, as attached from the following quote, a pair of $\mathrm{ABG}$ friends who initially lived their teenage days naturally and normally began to enter the dark side of life. From this plot, it can be seen that the impression that is reaped is a paradoxical contradictory picture if you look at the situation of adolescents in such discourse. Wherefrom this explanation that normally the teenage phase is related to the depiction of a cheerful life and various fun stories, not highlighting tragic or dark things.

From the author observation that the situation of adolescents who are described as different adolescents in the sense that they are not like adolescents who are usually encountered daily in general. As in the following text "super dark times is about friendship, and how a pair of teenage friends with all their innocence must face a dark reality". The word "innocence" refers to a character that has a sense of simplicity in attitude and behavior and mind and heart have a sense of honesty. Then it ends with the word "dark" at the end of the sentence, the word dark describes how gripping events in the story and also as a form of affirmation of the horror imagery that is discouraged in the story conditions from Super Dark Times.

However, if we further examine the words "innocence" and "dark", it becomes a common thread of how the postmodern form is represented. The two syllables can be both a link and a gap as the form of postmodern style is defined, namely, in the form of contradictions wherein the concept of a story, the melancholy drama is brought together in a tense and tragic nature. So that the identity of teenager as an innocent but naive character turns into an unusual teenager, even darker. The postmodern identity is how the constructed horror discourse is no longer a monotonous thing or is always associated with ghosts or supernatural beings. However, it is extraordinary that the melancholy drama about friendship can become a new horror discourse. Besides, the influence of the setting where the story can be pulled back to the previous time which is then brought back into a retro phenomenon. This is how the postmodern style is built.

b) Relation: In the second text article above, the participants or elements of the relationship that can be identified in the text are the involvement of the 90s and today adolescents. The two groups of phases try to be linked in terms of conditions, culture, and society. Where the retro nature or 90 s style tries to be brought back through the events discussed by the author. As in the following text, "For those who grew up and experienced their teenage phases in the $90 \mathrm{~s}$, of course, they will remember that this era was a simple and fun era " the word "they" in the sentence is addressed to readers who have had a similar experience with the author. The word "simple and fun" refers to the adjective of the expression of happiness, this can also be a measure of happiness that the author tries to construct that the $90 \mathrm{~s}$ or $90 \mathrm{~s}$ phase is socially culturally very influential for the author. And through the text above, it can be said to be a discourse of appreciation for the past phase to the present which certainly has different conditions.

Then, to emphasize how horror that has a similar condition, the writer also involves recommended films as supporting text participants, by writing the following sentence, "This reminds me a little of Stephen King stories of friendship and trauma, such as in IT (1990/2017) or Stand By Me 1986". The word "remembering" in the text above is an effort to compare similar events experienced by other films that are still in the corridor of horror. The film IT and Stand By me become an element of relation or participant by the writer as a measure or reference which stylistically has a similar story, namely bringing back the concept of the past or retro which is brought back to the present reality and incidentally combines two paradoxical stories namely drama horror.

c) Identity: The identity or placement of the writer position in the text lies in the writer identification of the story phase and self-positioning of the teenage characters. as in the following text ", the story of this film is quite dark, especially when realizing that these children are still in the ABG phase, a phase where they should have more fun without worrying much". From these paragraphs, we can see how the writer proly identifies that this film is included in the horror cluster that is ambiguous or paradoxical in terms of taking unexpected characters and characterizations.

In this second review of the text, it is clear that the writer is the liaison of the course of events, gaining power in reviewing the film so that the constructed discourse has a lot to do with the phases or conditions experienced by the author, as in the following text, I cannot imagine that they should be in their position as a teenager. In this sentence, it is clear that the writer emphasizes the postmodern style of horror paradox by using the phrase "I cannot imagine" which further clarifies how the author position mediates the narrative by watching the film, coupled with the following text, this film describes 
feelings of loss, guilt, and isolation, despair, inner conflict, and anger of teen.

\section{3) Ex Machina}

a) Representation: The positioning of horror identity in the review of the text, how the relationship between artificial intelligence and horror can create a differentiation process and an alternative for horror identity. It becomes an ambiguous projection to digest, as in the following sentence: "Ex_Machina is a brilliant film. Beautiful and enchanting but there is a separate horror behind it. In my eyes, the Ex_Machina film has a pretty terrible basic idea about technology, and it could come true if humans do not control their creation "

From the sentence above, the writer tries to convey how the postmodern style of horror exists differently and there is an alternative message from the impression of the film. The word "brilliant" in the first sentence is linguistically interpreted as a form of intelligence or has great reasoning and knowledge, the word brilliant can be concluded as a generality from how the construction of horror is represented in a genius way, which is captured by the author. From there the beginning of the contradictory events where the contradictory definition here is a gray projection image. This can be seen in the following sentence, namely "beautiful and enchanting but there is a separate horror behind it". were the words beautiful and horror become one common thread of the story connected by the word "however", use of words but as a description of the relationship between clauses. Where, through the word, however, it is an attempt to connect two realities, namely "Beautiful" and "Horror". The word Indah in the text clearly shows in the projection an image that is pleasing to the eye and has a positive aura rather than a negative one. Then at the end of the sentence, the word "horror" is inserted to support a contradictory picture as well as how horror culture is inserted. The word horror in the sentence is translated as an adjective from an expression of horror and fear. The result of the two contradictory syllables makes the conditions ambiguous. The word Indah in the text clearly shows in the projection a picture that is pleasing to the eye and has a positive aura rather than a negative one. Then, at the end of the sentence, the word "horror" is inserted to support a contradictory picture as well as how horror culture is inserted. The word horror in the sentence is translated as an adjective from an expression of horror and fear. The result of the two contradictory syllables makes the conditions ambiguous. The word Indah in the text clearly shows in the projection the image is pleasing to the eye and has a positive rather than negative aura. Then at the end of the sentence, the word "horror" is inserted to support a contradictory picture as well as how horror culture is inserted. The word horror in the sentence is translated as an adjective from an expression of horror and fear. The result of the two contradictory syllables makes the conditions ambiguous.

b) Relation: In a review written by the author, the participant or element of the relation presented in the text is the reader himself. The writer hopes that there is an exchange of ideas between the text and the reader. As in the following sentence, "But what happens if technology like this becomes smarter and more narrow-minded than humans? Or has technology falling into the wrong hands?" In this sentence, it appears that the author conveys his observations on the existence of technology today, the word "smart" refers to the greatness of the existence of technology itself, but on the one hand the word "petty" is presented as an expression of superficiality or tense tactics caused by technology.

Intelligent and petty are connoted as a condition of ambiguity, that the role of technology is like a double-edged knife, where its function can be misunderstood but can also be useful. Then the question mark symbol in the sentence, as an effort to exchange ideas between readers and writers. With this, the author does not want to immediately assume the full text he wrote. The writer observation and knowledge cannot be a concrete and absolute interpretation, but it can be a multiinterpretive thing because the audience is involved in the process of interpreting the message, the audience determines the agreement in perceiving the text. This is what identifies that in this sentence, the writer tries to give an active impact where the culture of discussion will be created through the review of the film Ex Machina written by the author. In linguistic practice.

c) Identity: The identity of the writer in the text is projected on how the pros and cons of responding to the film and how the imagination of the writer responds to the film. In terms of horror, the writer is still relatively pro with it, as in the text the following "In my eyes, the Ex_Machina film has a pretty terrible basic idea about technology, and it could come true if humans do not control their creation" the phrase "in my eyes" refers to the situation and conditions the writer gets when seeing the picture of the scene from the film Ex. Machina, that the fundamental thing of the identity of author is the projection of horror and how the projection of hyperreality that intersperses the picture of events from the film Ex Machina. As can be seen, the writer uses the word terrible as the identity of the horror projected in the film, but on the one hand, the word terrible is also identified as a skeptical attempt about hyperreality, where the direction of destruction or a dark image can be obtained if humans cannot control technology.

\section{B. Discourse Practice Analysis}

In addition to text analysis, Norman Fairclough model also analyzes discourse practice or discourse practice in the media. In this case, the concern is the text production process. In this section, the researcher will describe several things in the practice of discourse.

Talking about the things behind the creation of Journal content as an alternative packaging in website development as a medium. Vidi as the owner of the Maternal Disaster brand revealed that since the beginning of the website, they wanted to fill it with what they like and want. Maternal Disaster does 
not have a definite vision and mission with what they do like companies in general, in the sense that Maternal Disaster does not want to be too influenced by things that are structural or too pegged, on the schedule notes in a plan that must be neatly arranged and must be done regularly.

Discussing the media from the perspective of Maternal Disaster, if we further examine the creation of this phenomenon, it is undeniable that it is also necessary to see the actions of the communicator in enforcing the media, Vidi as the owner of the Maternal Disaster brand, with his passion for literacy contributed greatly to the emergence of Journal content on the media platform. on the website www.maternaldisaster.com. He admits that he is concerned about written works or archiving visual works into written form, where archives through such media are considered as recordings which can later become separate artifacts, where people can access or read stories. for the sake of the story from the resulting text.

Journal content on the website www.maternaldisaster.com is an initiation from Vidi, which is an expansion of interest by Vidi in the world of literacy. In filling out the content of the Vidi Journal, it has a writing flow mechanism or editorial flow that is different from mass media in general, Maternal Disaster enforces its website unlike in mass media organizations which have editorial teams such as editors, journalists, editors. The text production process is left between the writer and Vidi, and in the media routine, Maternal Disaster gives freedom to the writer is exploring the resulting text. This format is what distinguishes it from mass media institutions in general, which have a procedural flow mechanism, from finding sources of written material to the release of published articles. Besides, the content of Journal does not have a qualified media organization like mass media organizations in general in managing media. This is because they are a brand whose organization focuses more on brand institutions that use new media with a website platform as a medium to bring Maternal Disaster closer to the market or audience.

In choosing the films to be reviewed, the writer is given flexibility in choosing the film to be reviewed, however, the themes of film already have a horror corridor according to the expectations of the Maternal Disaster brand. The flexibility and exploration of the text by the writer to produce the text can be intertwined because emotionally the relationship between the writer and Vidi in the circle of friends is quite close, the author is a relative of Vidi who characteristically has the same passion in terms of film lovers so that the writer in content Journal has the freedom itself in choosing the topic of the film to be reviewed, but that freedom certainly has consequences, namely following the corridor of the nuances and characters of Maternal Disaster which tend to be dark and influenced by the spectrum of black tones.

Review Horror films are one of the subcontent of the content of Journal, it is not a coincidence to review horror films. Vidi revealed that horror films are the primary intake that influences the creation of the Maternal Disaster brand itself, this is represented by black tones and dark nuances that are displayed on every Maternal Disaster product. So that it becomes a separate identity for both Maternal Disaster and the audience for the Maternal Disaster brand. Personally, Vidi admits that he has his passion for horror films, so the personality between the brand and the owner has the same relevance. This triggers the influence of the popular culture of horror films that make a reality.

The individual aspects of the writer such as gender, scientific background, culture, and career path are sufficien factors to determine how the production of the text is constructed. The author of the three texts that the researcher analyzed was an article reviewer from Dani. He is one of the writers who fill in the journal content at www.maternaldisaster.com, interrupted as a writer at www.maternaldisaster.com he is also an illustrator / artworker with a horror / dark concept illustration character, he also has an interest and knowledge about the world of horror and Science fiction is what represents the films he consumes.

In the text production process, there is a discourse process that shows the existence of relational values between participants in the text, such as the identity of the author, as well as the departure from the brand identity of Maternal Disaster itself. To understand that, we must remember that the text production process occurs because of the process of interpretation by the author on a topic or issue in a film that wants to be reviewed, which in this context includes the flow of the postmodern movement.

As in the movie reviewer Video Drome, the horror phenomenon, which from the interpretation of author is how mass media such as TV, especially audio-visual shows of violent scenes, can influence the audience and even brainwash the audience. From psychology, the experience of fear makes TV media into something horror. Then in Super Dark Times, the horror phenomenon from the interpretation of author is the traumatic experience of a pair of teenage friends who initially lead a normal and normal teenage life filled with laughter. The innocence and naivety of a teenager can enter the dark side with violence and blood, which is not unexpected from a teenager who can go through such a brutal phase. And the last is in Ex Machina where the horror phenomenon of the interpretation of author is the horror of technology such as Artificial Intelligence. The depiction of horror lies in how Artificial Intelligence technology is if artificial intelligence can be beyond human control or can be even prettier than humans, it can be something dark and terrible for humans. While the context that supports the postmodern viewpoint, in the 3 reviews is the imagery of interpretations and representations that go beyond imagination and fantasy plus contradictions in the creation of horror characters where themes such as media, technology, science fiction, and teenage romantic life are depicted as something terrible.

With such an interpretation, we can see how the selfdetermination of the author, the participants, and the Maternal 
Disaster brand itself, which as a whole is a process of discourse production, the researcher sees how the writers take sides with postmodern horror styles in interpreting text discourse.

Postmodern text discourse is balanced with the Maternal Disaster style itself, which offers something different between similar streetwear themes and provides a new alternative in consuming media by presenting Journal content on the Maternal Disaster website. So that the text produced by the author professionally in working on film reviews in Journal content on Maternal Disaster media is a reflection of the consumption of popular culture by Maternal Disaster.

\section{Sociocultural Practice Analysis}

In this section, researchers will attempt to describe sociocultural practices or social practices that exist when texts on postmodern lifestyles appear on www.maternaldisaster.com. According to Eriyanto [12], Fairclough divides the analysis of social practices into three parts, namely situational, institutional, and social. The situational context describes the peculiarities of a situation that encourages the presence of the text. The institutional context explains how the influence of institutions or organizations in discourse production practices. Institutions in this case can be internal media itself or external institutions. Meanwhile, the social context explains more broadly the conditions of the political, economic, social, and cultural systems.

1) Situational: Concerning the consumption and production of Maternal Disaster in consuming movie shows, many are influenced by horror film shows which tend to be postmodern. In the perspective of postmodern conditions, horror films have differences in personification and identification with classic films. Pinedo [19] exposes a postmodern horror film revolving around the ineffective attempts of ordinary people to fight violent monsters, supernatural invaders or aliens, perverted transformations from within, psychotic, or a combination of these forms. The boundaries between life and death, normal and abnormal, human and aliens, and good and evil are blurred and sometimes indistinguishable. And, unlike classic horror films, postmodern films place horror in a transient everyday world, where skilled male experts are replaced by casual victims who experience high levels of explicit sexual violence. The postmodern genre promotes a paranoid worldview in which increasingly inexplicable and increasing internal threats to social order prevail.

The discourse from the film review articles published in the content of Journal describes a lot of horror discourse in a postmodern view. This means that the horror raised is not something conservative like defining ghosts or other astral creatures or urban legend stories. The discourse of horror here is more contradictory, where horror, fear, and darkness are involved in the discourse of technology, media, and humans. Until the depiction of daily realities in the life of teenage friendship with all its innocence, discourse can become a tense and traumatic romance drama. Science fiction or drama themes like that condition something abnormal.

Seeing the consumption and production of the popular culture of horror films by Maternal Disaster, in postmodern phenomena, it can also be called a simulation process which will eventually take the form of a hyperreality condition. Keisner [20] describes that horror films have become postmodern, partly because they question reality; they encourage viewers to consider their ideas of what is real. Horror films are simulations of reality, or rather, they are included in Jean Baudrillard definition of simulacra or a creation of a reality that never existed. One of the important characteristics of horror films is science fiction or the supernatural element.

Maternal Disaster takes the embodiment of the representation of horror discourse into their products, seeing the horror discourse they consume, which they then reproduce into a creation of new models of their horror experiences into the product of Maternal Disaster, to create conditions of hyperreality, such conditions make style. life in the postmodern.

The text discourse on horror culture on its relevance to the brand makes a gamble between the value of consumption and productivity on the shadows of popular culture by horror culture consumed by brands, in this case, Maternal Disaster. The postmodern lifestyle of the text is implicitly raised, in the sense that the message in the discourse of text is not clearly expressed, but implicitly through text fragmentation with an intertextual concept where the text is divided between the language of the film and the language of the writer. so that the explanation of the text in the journal content is a form of representation and the subjectivity of the author of a movie that is watched or consumed, which then returns to text (linguistic) in the film review article.

2) Institutional: In his actions in the flow of image or image formation, Maternal Disaster played more in the underground scene, be it fine art or music. This includes appreciating and contributing to underground/independent music events and contemporary art exhibitions.

Collaboration between discourse from horror films and underground/metal music has identified an identity that cannot be separated from the construction of a brand image. The two popular subcultures seem to have their respective roles but have a close relationship. In terms of space, see how the underground/metal music scene is so close to Maternal Disaster, that the attraction of identifying horror is a supporting part of the underground/metal musical approach. So that from the process of identifying the image, it forms a relationship in the streetwear product as a special attraction in providing differentiation and alternative consumption of Maternal Disaster streetwear products.

In the case of the postmodern style, the fusion between horror popular culture from film and underground/metal music 
into a solid mix has an identity that is distinct from the medium but can also be a new alternative from the perspective of horror and underground/metal music to form a representation of a hybrid lifestyle, in obtaining a distinct identity into streetwear brand products from Maternal Disaster. Besides, the form of horror in the discourse of the text of the film reviews in the Journal content takes many elements of a cross between two contradictory characters, namely elements of science, romantic drama, and horror culture.

The postmodern style that Maternal Disaster discusses in its content is a representation of Maternal Disaster, forms such as hyperreality and hybridity that appear contradictory, become an identity for Maternal Disaster in consuming popular culture they absorb which impacts on the style of their streetwear products. Plus the horror / dark character of the brand is still the strong dominance of labeling the market from Maternal Disaster. The identity transmitted by Maternal Disaster is the subjectivity of experience from the internalization of the Maternal Disaster which is developed outside their internal, which is a unique and uncertain cultural product because it takes the role of a horror subculture from a popular culture projection involving the identity of the underground music scene. metal.

In terms of the proportion of media consumption involvement with its product style, Maternal Disaster as a streetwear brand was originally only engaged in clothing, now it is expanding to products that are more than just clothing, such as accessories such as helmets, umbrellas, basketball, and others. Even outside the context of streetwear products in general, formal uniforms from Senior High Schools (SMA) are also produced in current Maternal Disaster products. It is a reflection of the postmodern style which is contradictory or runs away from the structural nature of the modern style. Besides, the projected collaborations that mix and match various types of brands outside of the institutional from Maternal Disaster are also expressed in their products, This phenomenon offers new differentiation and alternatives to the subculture of the streetwear movement. Seeing this case, the similarity of the postmodern style of the discourse of the film reviews that they produce in their content, which has contradictory requirements, becomes a reflection of the projected product style. What kind of subculture mapping is currently being developed. Seeing the manifestations of what Maternal Disaster has done on the discourse given, there are several activities in developing the identity they created, namely: first, media consumption and production activities for popular culture developed by Maternal Disaster, second, Journal content activities when reproducing through a text discourse, whose knowledge content is heavily influenced by the media consumption and popular culture of Maternal Disaster.

Social: The discourse of popular culture is also closely related to the hegemony of capitalism, if you look at this context, journal content is one of the content in www.maternaldisaster.com try to practice a hegemony to the audience over popular culture which is consumed by Maternal
Disaster itself. so that everything that is displayed in the content along with the contents of the text is a reflection of the Maternal Disaster brand identity. As stated by Bungin [1] hegemony can also be seen as part of a capitalist tool in constructing an ideology of society of self and its life needs.

Looking at the issue of Maternal Disaster, how postmodernism can become a lifestyle in an institutional setting, even what kind of expansion has caused the discourse of postmodern lifestyle to hit in Indonesia, especially in the case of streetwear products, what events serve as forms of differentiation and alternatives if they are linked to political events. If we look again at how this cultural industry can happen, first seen from a flashback of political tendencies from the New Order, then the political tendencies in the reform era, where both political eras have gaps in the acceptance of this kind of cultural industry. especially on the issue of horror culture, which is often close to the underground/metal music scene, which has an impact on the Maternal Disaster brand movement.

In Indonesia, the bad stigma against metal music is different from that in western countries. The issue of antiChrist and Satanism is not a big problem. Metal is identified with a wild, brutal, and anarchist spirit that is incompatible with the Pancasila narrative and the order that the New Order regime wanted [21].

Lukisworo and Sutopo [22] Metal is a cultural product that is synonymous with resistance. However, in youth studies, especially with a subcultural perspective, the position of metal tends to be marginalized and marginalized. In the Indonesian context, metal is more often placed within the framework of ideological contestation with elite groups in the economicpolitical sphere. Baulch, explained that the beginning of metal development at the national level in Indonesia was marked by criminalization and politicization. Criminalization emerged when there was a riot at a Metallica concert in Jakarta in 1993 , as a result, metal was identified with thuggery by the New Order regime at that time.

Unlike the New Order regime which was repressive towards the underground/metal scene, in the reform regime, popular culture products were openly accepted without any identification with thuggery or anything brutal in the underground/metal scene, especially in the era of Joko Widodo leadership as president of the Republic of Indonesia Lingga Agung Partawijaya in Adlin [23] explains that the underground music scene in Indonesia continues to experience significant growth significantly. Especially since the collapse of the New Order and the rise of Joko Widodo as president of the Republic of Indonesia, who is said to be a metalhead, the popularity of the underground music scene has become widely recognized.

So that the political and economic tendency of postmodern lifestyle in the streetwear discourse that intersects with underground/metal music culture or horror culture has a significant influence on its development in this country. Especially in politics in the reform era, where the upheaval of 
popular culture is increasingly in demand, which used to be limited to consumption alone, now in the reform era, it can become a reproduction that has its advantages in economic value. It is undeniable that the result of this political acceptance has made the consumption of popular culture a postmodern lifestyle in social order to its relevance to capitalism, as we know that popular and postmodern culture has such intimate attachments, and cannot be separated from one another.

\section{CONCLUSION}

Based on the study and data analysis from the text of the movie reviews on the Journal content on the website www.maternaldisaster.com By using a discourse analysis model of Norman Fairclough, the researchers conclude this study.

- Based on the text analysis side of the 3 film review articles in the journal content at www.maternaldisaster.com, the discourse on the postmodern lifestyle that is discouraged is closely related to the ambiguity, contradiction, and paradoxical nature of postmodern style discourse. The relationship of writer with the text is built on knowledge from the popular culture of film spectacle, especially regarding the postmodern horror style discourse. The nature of this ambiguity, contradiction, and paradox becomes a form of differentiation and alternative from a horror discourse in discouraging horror, fear, and darkness. So that the discourse is considered as brilliance and skepticism about the horror projection is placed.

- In terms of the analysis of discourse practice, the three texts contained in the content of Journal cannot be separated from the intrapersonal influence of the Maternal Disaster brand owner and also the author on Journal content who does have the same pleasure in consuming popular culture from horror films, especially horror with a postmodern style. Regarding the postmodern lifestyle discourse, it becomes a reflection on the internal style in the practice of the discourse process in journal content, where the creative freedom between Maternal Disaster and the author in providing flexibility in access to text writing provides identification of the text with the author of the brand alone. So that the interpretation of the text that is discouraged is born from the knowledge writer of media consumption and popular culture. The birth of this content is a culture of sharing horror reference knowledge by Maternal Disaster to the public for their consumption of film popular culture. The hyperreality and hybridity of the postmodern horror style concept become a reflection of the personal and institutional identity of Maternal Disaster in the streetwear brand image. So the practice of consumption, production, and reproduction of the Journal content becomes a process of developing innovation and creativity in media and business prospects.
- In terms of analysis of sociocultural practice, it is inseparable from social practices that involve political, economic, and cultural contexts at the level of social practice. Postmodern lifestyle includes consumption of media and popular culture, the discourse of postmodern horror style ignites the concept of hyperreality of media consumption. Maternal Disaster as a streetwear brand is very close to the underground or metal scene, so that through popular culture, horror and metal experience medium hybridity, plus a spectrum of horror fragmentation, which is close to dark shades identical to underground/metal. In political contestation, the triggering of postmodern lifestyle after the New Order phase to reform where popular culture was accepted massively had an impact on the economy, wherein the underground/metal scene was accepted both politically and economically. The ideologies of capitalism and postmodern mutually resonate in determining sociocultural shifts by looking at the growth of lifestyles in the flow of differentiation and alternatives to selfidentification in the vortex of social problems.

\section{REFERENCES}

[1] M.B. Bungin, Konstruksi Sosial Media Massa. Kencana: Jakarta, 2008.

[2] D. Chaney, Lifestyle: Sebuah Pengantar Komprehensif. Yogyakarta \& Bandung: Jalasutra, 2009.

[3] Y.A. Lubis, Postmodernisme: Teori dan Metode. Jakarta: PT Rajagrafindo Persada, 2014

[4] G. Burton, Pengantar Untuk Memahami: Media dan Budaya Populer. Yogyakarta: Jalasutra, 2008.

[5] A. Sobur, Analisis Teks Media: Suatu Pengantar Untuk Analisis Wacana, Analisis Semiotik, dan Analisis Framing. Bandung: PT Remaja Rosdakarya, 2015.

[6] P.L. Berger and T. Luckmann, The social construction of reality: A treatise in the sociology of knowledge. Anchor, 1966.

[7] A. De Fina, "Introduction" in Anna de Fina. Deborah Schiffrin dan Michael Bamberg (ed). Discourse and Identity. Cambridge: Cambridge University Press, 2006.

[8] D. Kellner, Budaya Media: Cultural Studies, Identitas, dan Politik antara Modern dan Postmodern. Yogyakarta: Jalasutra, 2010.

[9] Pawito, Penelitian Komunikasi Kualitatif. Yogyakarta: LkiS, 2007.

[10] R. Ida, Metode Penelitian Studi Media dan Kajian Budaya. Jakarta: Kencana, 2016.

[11] A.Y. Piliang and J. Jaelani, Teori Budaya Kontemporer. Yogyakarta: Cantrik Pustaka, 2018.

[12] Eriyanto, Analisis Wacana: Pengantar Analisis Teks Media.Yogyakarta: LkiS, 2001.

[13] K.S. Santana, Jurnalisme Kontemporer. Jakarta: Yayasan Pustaka Obor, 2017.

[14] P. Kotler and G. Armstrong, PrinsipPrinsip Pemasaran. Jakarta: Erlangga, 2008.

[15] G. Heryanto, Komunikasi Politik Se- buah Pengantar. Jakarta: Ghalia Indonesia, 2013.

[16] A. Hadi, Matinya Dunia Cyberspace. Yogyakarta: LKiS Yogyakarta, 2005.

[17] E. Ardianto, Metodologi Penelitian Untuk Public Relations. Bandung: Simbiosa Rekatama Media, 2014. 
[18] L.J. Moleong, Metodologi Penelitian Kualitatif. Bandung: PT Remaja Rosdakarya, 2014.

[19] I. Pinedo, "Recreational Terror: Postmodern Elements Of The Contemporary Horror Film," Journal Of Film and Video, vol. 48, pp. 17-31, 1996.

[20] J. Keisner, "Do You Want to Watch? A Study of the Visual Rhetoric of the Postmod- ern Horror Film," Women Studies, vol. 37, no. 4, pp.41127,2008 .
[21] Y. Mangoenkoesoemo and G. Soerjoatmodjo, Heavy Metal Parents: Identitas Kultural Metalhead Indonesia 1980-an. Yogyakarta: Octopus Publishing, 2018.

[22] A.A. Lukisworo and O.R. Sutopo, "Metal DIY: Dominasi, Strategi, dan Resistensi," Jurnal Studi Pemuda, vol. 6, no. 2, pp. 579-589, 2019.

[23] A. Adlin, Trialektika: Agama, Budaya, Politik. Bandung: Pustaka Matahari, 2017. 